\title{
WATER CONTENT OF MIXED HONEY BEES-COLLECTED POLLEN
}

\author{
Zheko Radev
}

\begin{abstract}
Absract: The knowledge of the water content of pollen is important to determine the amount of protein content, lipids, sugars, minerals and other components in the dry matter. The water content of mixed honey bee-collected pollen was determined by a method of drying. A table of the water content in the mixed pollen from different harvesting periods was made. The percentage of water content in the mixed bee-collected pollen samples ranged between $12.3 \%$ and $26.6 \%$ and the average was $18.8 \%$. Pollen from different harvesting periods has different water content. There are also differences among the same months during three years. The average value of water content for each year is also different. According to the results, can't be said during which season (spring, summer, autumn) the pollen has higher or lower water content. Ecological factors, especially rainfalls, can also affect water content.
\end{abstract}

Key words: water content, pollen, honey bee, method of drying

\section{INTRODUCTION}

Water plays an important role in the diet of honey bees, but is not essentially contained in the pollen. The percentage value of moisture in the pollen species collected by bees, was found to be $11 \%$ and in the range of $7-18 \%$ [1]. The water content of honey bee-collected pollen from 50 plants from Bulgaria range between $9.69 \%$ for Centaurea calcitrapa and $23.12 \%$ for that of Crepis sp. and the average is $17.35 \%$. Pollen from various botanical species has different water content. There are also differences among different species of plants of the same family. The anemophilous species- Juglans regia and especially Chenopodium sp. and Atriplex patula had one of the lowest water content, while Plantago sp. and specifically Amaranthus retroflexus had one of the highest water content. The introduced plant Zea mays, Salix sp. and Morus nigra occupied a middle position in the results. No differences were found in the water content of pollen between the anemophilous and the entomophilous species [2]. It was found that the average value of moisture content in ten samples of dried pollen originating from isolated plant species was 7.4\% [3]. An average of $16.48 \%$ moisture in pollen was estimated [4]. The average moisture of freshly collected and dried pollen calculated by [5] was $18.3 \%$ and $6.2 \%$, respectively. The amount of moisture in pollen plays an important role for the preservation and storage of products [6-8], while was proposed to add the amount of moisture in pollen to the quality criterion [9]. Ecological factors, especially rainfalls, can also affect water content [2].

It is necessary to know the water content of pollen in order to determine the amount of protein content, lipids, sugars, minerals and other components in the dry matter. In the available literature, there is no information on the water content of mixed honey bee-collected pollen in Bulgaria.

\section{MATERIALS AND METHODS}

Pollen traps were placed in five bee hives and the pollen pellets were harvested every 2 days from April to September in the area of Belozem (42.201860, 25.049330), Bulgaria. Around 75 samples of the beecollected pollen were collected. Every month has two reporting periods: I period from $1^{\text {st }}$ to $15^{\text {th }}$ day of the month and II period from $16^{\text {th }}$ to $30 / 31^{\text {st }}$ day of the month. The pollen loads of each hive were carefully mixed and a sample of $10 \%$ [10] was taken by the quarter method of sampling. First, the pollen was spread on paper and divided into four equal parts. Then two opposite diagonal quarters were removed. The remaining material was mixed and quartered until the sample was reduced to the desired size. The pollen samples were labelled and stored in separate vials in a freezer at $-20^{\circ} \mathrm{C}$.

The method of drying at $103^{\circ} \mathrm{C}$ was used for the determination of moisture content in the pollen samples. A quantity of $1 \mathrm{~g}$ of pollen was accurately weighed in a porcelain-evaporating dish and was placed at $103^{\circ} \mathrm{C}$ in a oven, for 2.5 hours.

The water content was estimated as the difference in weight of the dried samples before and after introduction into the drying oven.

$$
\begin{aligned}
& \text { Water } \%=M-M_{1} / M-M_{2} \times 100 \\
& M-\text { dish and sample weight }(\mathrm{g}) \\
& M_{1} \text { - mass weight with sample after drying }(\mathrm{g}) \\
& \mathrm{M}_{2} \text { - weight before adding the sample analysed }(\mathrm{g})
\end{aligned}
$$

\section{RESULTS AND DISCUSSION}

According to the analysis, a table with the water content of mixed honey bee-collected pollen has been compiled (Table 1). The study results showed that the water content of the mixed pollen varied for the two reporting periods of each month and for each single month (Table 1). The percentage of water content in the mixed bee-collected pollen samples 
ranged between $12.3 \%$ and $26.6 \%$ and the average was $18.8 \%$. Pollen from different harvesting periods has different water content. There are also differences among the same months during three years. For 2012 the range was from $12.3 \%$ to $20.8 \%$, the average value was $16.7 \%$, for 2013 it varied from $16.8 \%$ to $26.6 \%$, the average value was $20 \%$ and for 2014 it was from $14.7 \%$ to $24.6 \%$, the average value was $19.4 \%$. The average value of water content for each year is also different. The statistical analysis (at $\mathrm{p} \leq 0.05, \mathrm{p}=0.02$ ) of the results of the experimental work during the three years of research showed significant difference to increase the water content of the pollen in 2013 and 2014 comparison to 2012. The increasing tendency probably came from the dynamic change of the ecological factors especially the rainfall. During 2013/2014 there were more rainy periods comparison to 2012 (Fig. 1, 2 and 3). Ecological factors, especially rainfalls, can also affect water content.

According to the results, can't be said during which season (spring, summer, autumn) the pollen has higher or lower water content.

Table 1. Water content (\%) of mixed pollen in different harvesting periods for three years

\begin{tabular}{|l|c|c|c|}
\hline Harvesting periods of pollen & $\mathbf{2 0 1 2}$ & $\mathbf{2 0 1 3}$ & $\mathbf{2 0 1 4}$ \\
\hline April 1-15 & & 20.6 & 19.9 \\
\hline April 16-30 & 13.6 & 18.2 & 24.6 \\
\hline April (average value) & $\mathbf{1 3 . 6}$ & $\mathbf{1 9 . 4}$ & $\mathbf{2 2 . 2}$ \\
\hline May 1-15 & 20.2 & 18 & 22.5 \\
\hline May 16-31 & 20.8 & 16.8 & 18.4 \\
\hline May (average value) & $\mathbf{2 0 . 4}$ & $\mathbf{1 7 . 4}$ & $\mathbf{2 0 . 4}$ \\
\hline June 1-15 & 20.3 & 19.5 & 20.2 \\
\hline June 16-30 & 15.2 & 20.7 & 18.1 \\
\hline June (average value) & $\mathbf{1 7 . 7}$ & $\mathbf{2 0 . 1}$ & $\mathbf{1 9 . 2}$ \\
\hline July 1-15 & 15.9 & 26.6 & 14.7 \\
\hline July 16-31 & 18.1 & 22 & 18.8 \\
\hline July (average value) & $\mathbf{1 7}$ & $\mathbf{2 4 . 3}$ & $\mathbf{1 6 . 8}$ \\
\hline August 1-15 & 13.9 & 18.8 & 17.1 \\
\hline August 16-31 & 12.3 & 18.8 & 16.3 \\
\hline August (average value) & $\mathbf{1 3 . 1}$ & $\mathbf{1 8 . 8}$ & $\mathbf{1 6 . 7}$ \\
\hline September 1-15 & 14.2 & 19.5 & 19 \\
\hline September 16-30 & 19.9 & 20.9 & 23.3 \\
\hline September (average value) & $\mathbf{1 7 . 1}$ & $\mathbf{2 0 . 2}$ & $\mathbf{1 9 . 4}$ \\
\hline X for year & $\mathbf{1 6 . 7}$ & $\mathbf{2 0}$ & \\
\hline
\end{tabular}

Pollen is the source of protein necessary for vital processes of the honey bees [11]. The determination of the water content in the pollen is used to reveal the remaining dry matter content and to express the protein content, lipids, sugars, minerals and other components in the dry matter. The knowledge of the quality of the local pollen flora is very important for beekeeping. 


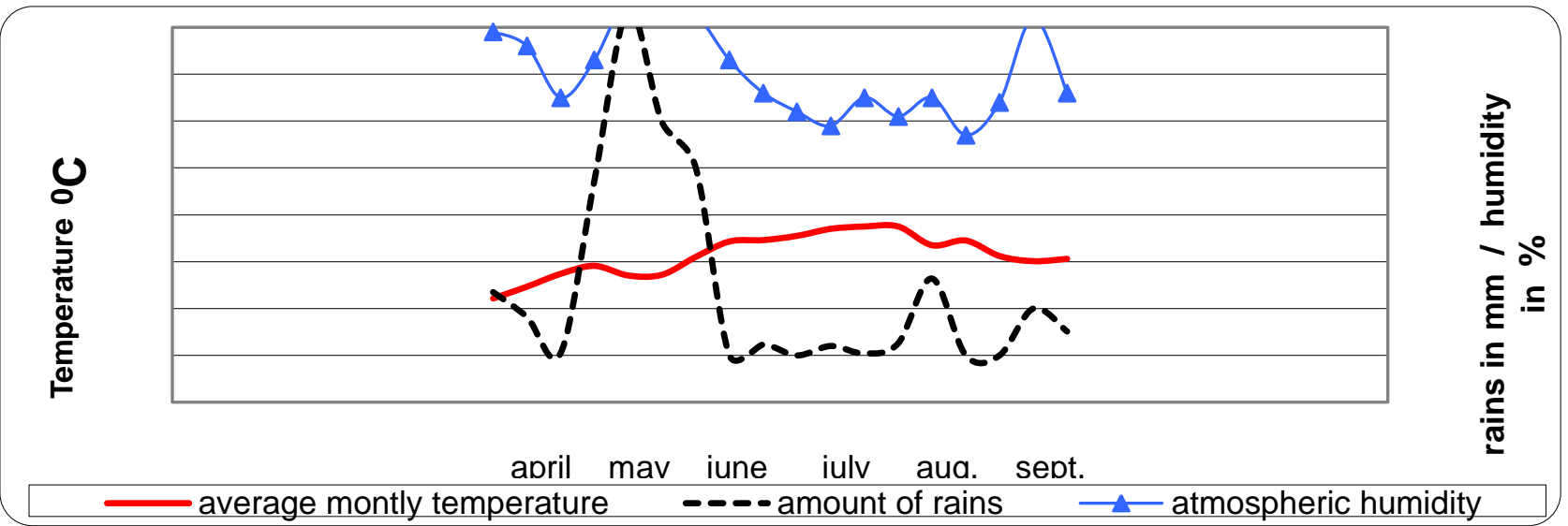

Fig. 1. Climatic characteristics of Belozem area for 2012

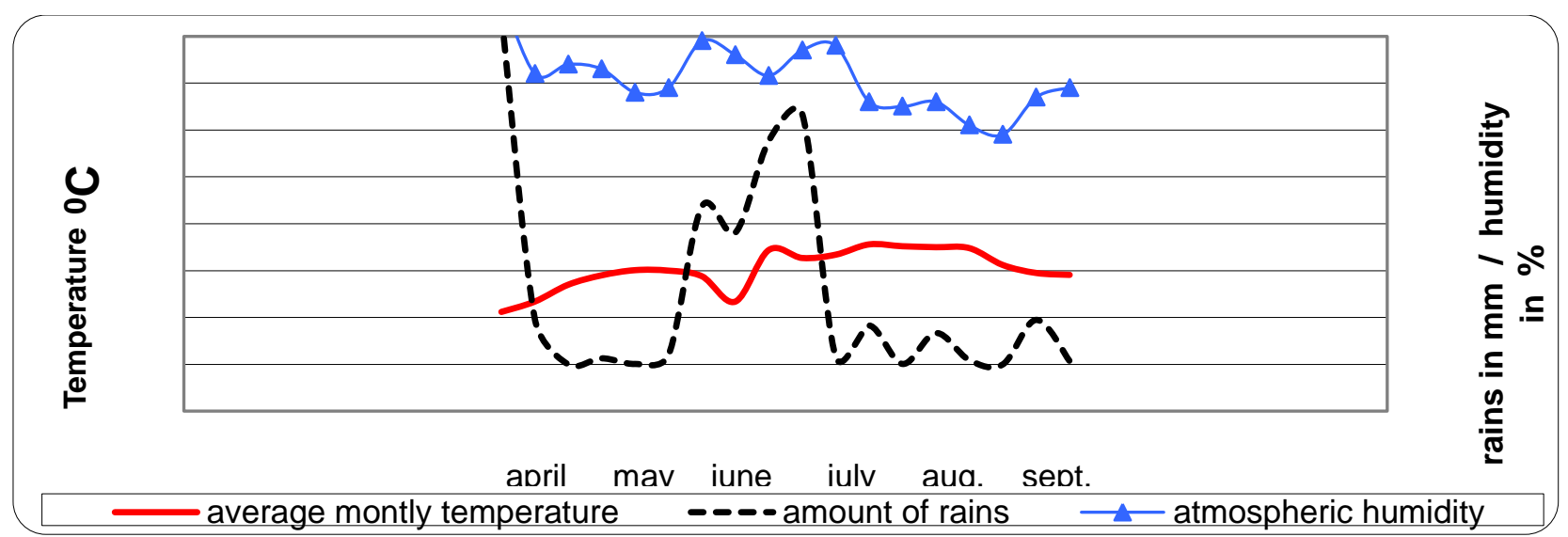

Fig. 2. Climatic characteristics of Belozem area for 2013

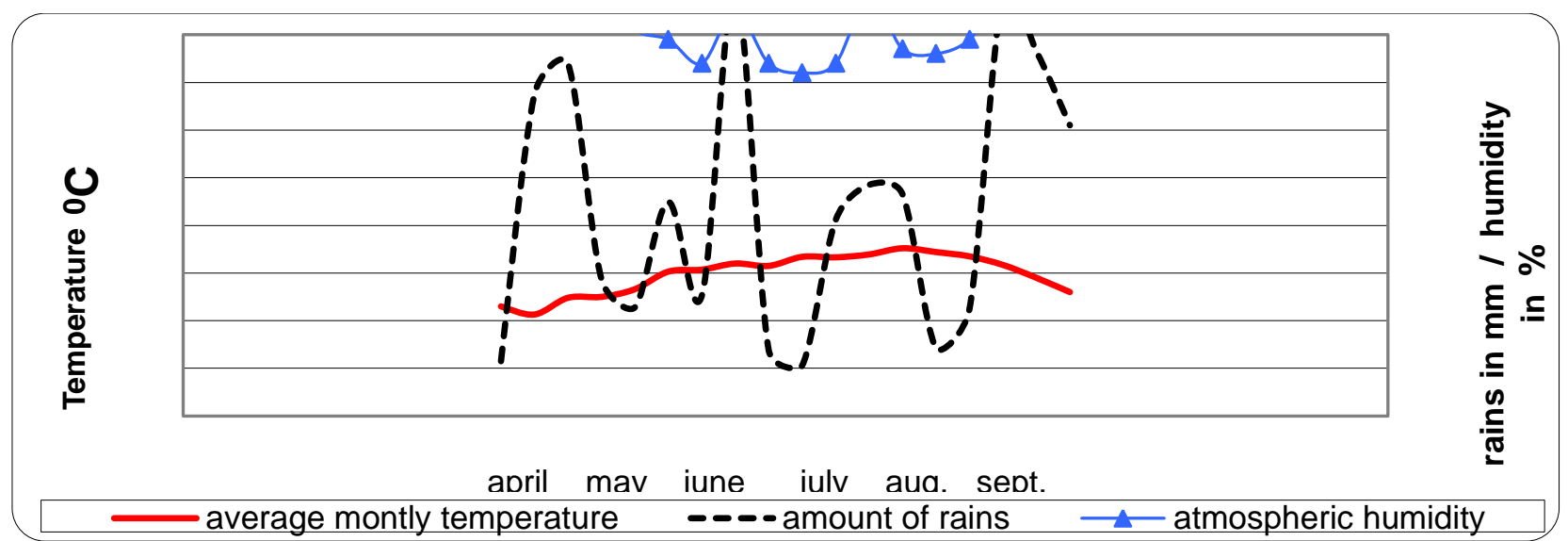

Fig. 3. Climatic characteristics of Belozem area for 2014

\section{CONCLUSIONS}

The knowledge of the water content of pollen is important to determine the amount of protein content, lipids, sugars, minerals and other components in the dry matter. The percentage of water content in the mixed bee-collected pollen samples ranged between $12.3 \%$ and $26.6 \%$ and the average was $18.8 \%$. Pollen from different harvesting periods has different water content. There are also differences among the same months during three years. The average value of water content for each year is also different. According to the results, can't 
be said during which season (spring, summer, autumn) the pollen has higher or lower water content. Ecological factors, especially rainfalls, can also affect water content.

\section{REFERENCES}

1. Iannuzzi J., Pollen: food for honey bee and man?, American Bee Jour., No. 8, Vol. 133, 1993, 557-563

2. Radev Z., Water Content of Honey Bee Collected Pollen from 50 Plants from Bulgaria, Mod. Conc. \& Dev. Agro., No.3, Vol. 3, 2018, MCDA.000563.

3. Muradian L., L. Pamplona, S. Coimbra, O. Barth, Chemical composition and botanical evaluation of dried bee pollen pellets, Jour. of Food Compos.and Anal., No. 1, Vol. 18, 2005, 105-111.

4. Liolios V., Record of pollen flora,protein content and sugar composition in bee-collected pollen, M. Sci. Thesis, Laboratory of Apiculture-Sericulture, Agricultural School, Aristotle University of Thessaloniki, Greece, 2010, 61-67.

5. Szczesna T., H. Rybak-Chmielewska, E. Was, P. Skubida, Water determination in bee products using the Karl Fischer titration method, Api. Sci., No. 2, Vol. 53, 2009, 49-55.

6. Szczesna T., H. Rybak-Chmielewska, H. Chmielewski, Sugar composition of pollen loads harvested at different periods of the beekeeping season, Api. Sci., No. 2, Vol. 46, 2002, 107-115.

7. Szczesna T., Protein content and amino acid composition of bee collected pollen from selected botanical origins, Jour. of Api. Sci., No. 2, Vol. 50, 2006, 81-90.

8. Szczesna T., Study on sugar composition of honey bee-collected pollen, Api. Sci., No. 1, Vol. 51, 2007, 15-22.

9. Campos M., A. Cuhna, K. Markham, Bee pollen composition, properties and applications, Proc. Conf. on Bee Products Properties, Applications and Apitherapy, Tel Aviv, Israel, May 26-30, 1996, 93-100.

10. Dimou M., A. Thrasyvoulou, Seasonal variation in vegetation and pollen collected by honeybees in Thessaloniki, Greece, Grana, No. 4, Vol. 46, 2007, 292-299.

11. Dietz A., The hive and the honey bee, Ed. Dadant \& Sons, J. Printing Co., Illinois, 1975, 1324 p.

\section{Zheko Radev, PhD}

Cosmocert S.A.

49A, Bulgaria Bul.,

Sofia , 1404, Bulgaria

e-mail: zhekoradev@abv.bg 